\title{
ANALYSIS OF ENVIRONMENTAL CONTAMINATION WITH BACTERIA AND FUNGI IN A BROILER HOUSE IN QENA, EGYPT
}

\author{
Sabry A. Hassan ${ }^{1 "}$ and Youssuf A. M. Gherbawy ${ }^{2}$ \\ ${ }^{1}$ Department of Microbiology, Faculty of Veterinary Medicine, \\ South Valley University, Qena, Egypt. \\ ${ }^{2}$ Department of Botany (Microbiology Division), Faculty of Science, \\ South Valley University, Qena, Egypt
}

\begin{abstract}
Environmental quality is much correlated with animal welfare. Microbiological status of a chicken broiler house environment in Qena city, Upper Egypt was investigated for total aerobic bacteria, fungal count, total coliforms, Escherichia coli, fecal enterococci, Staphylococci and Pseudomonads. Bacterial and fungal cultures from poultry feed, water, Litter, and air were undertaken every week throughout the 7-wk fattening period. The results showed that the indoor microbial contamination were generated and detected. It was revealed that microorganisms in air were detected at a mean value $\left(\log _{10} \mathrm{cfu} / \mathrm{m}^{3}\right)$ of 4.17 for total aerobic bacteria; 1.86 for total coliforms; 0.89 for E. coli; 1.59 for fecal enterococci; 2.78 for Staphylococci; 2.16 for Pseudomonads; and 2.59 for yeast/mold. The predominant bacterial species include $S$. aureus, Pseudomonas aeruginosa; fecal enterococcus, E. coli meanwhile Aspergillus flavus, Aspergillus fumigatus, and Candida albicans were among the mostly encountered fungal species. The results indicated an increase in air microbial concentration correlated with growth and age of birds. Microbiological examination of samples from litter, feed and water revealed contamination with one or more of microbial groups or species investigated. The present study revealed the occurrence of microbial contamination in poultry environment and strict hygienic measures should be considered for bird health performance and human and surrounding environment as well.
\end{abstract}

Keywords: broiler house; contamination; environmental; bacteria; fungi 


\section{INTRODUCTION}

Nowadays, one of the most important contaminants in the farming environment are bioaerosols. In poultry intensive production, chicken fattening in particular, is a significant source of air and surfaces contamination whereas many of birds housed and the haze of suspended dirt, feces, feathers and skin fragments, that may adversely affect the animal health as well as may pose a health risk for animal caretaker and those living in close proximity (Donham, 1993).

Environmental air monitoring programs can be employed to reduce unsanitary conditions in animal houses due to suspended bacterial and fungal particles in the air in order to assure a good environmental quality. Air quality with regard to poultry production, bird health and environmental contamination has been a major concern for years (Ritz et al., 2006). Poultry are known to harbor pathogenic microorganisms, and as such poultry house air can be contaminated with these microorganisms. A lot of microorganisms including bacteria, viruses, fungi, and parasites that can spread via air among animals and from animals to humans.

Health concerns impact not only the health of the birds, but also can affect the health of humans if they are exposed to high concentrations of bacteria and fungi as well as endotoxins and mycotoxins produced by them. There is epidemiological evidence that the health of farmers working in animal houses may be harmed by regular exposure to the highest concentrations of air contaminants such as gases, dust, microorganisms and endotoxins ( Whyte et al., 1993).

Airborne microbial populations and aerosol production has been examined in broiler houses, hatcheries and egg processing facilities (Clark et al., 1983; Sotohy, 1989; Whyte et al., 2001; Northcutt et al., 2004; Karwowska, 2005; Byomi and Trabees, 2006; Duan et al., 2008). 
For these reasons, it is important to analyze the microbiological status of poultry house environment for contamination.

The present work aimed to describe the relative abundance of bacteria, and fungi in a broiler poultry house. A 7 week surveillance study was undertaken for the detection on fungal and bacterial selected target species in the air, food, and litter. Water samples from drinker were evaluated for microbial quality. Selected target bacterial species including coliforms, E. coli, fecal enterococci, Staphylococci and Pseudomonads were assessed. Thermophilic fungal species including Aspergillus spp. and C. albicans, that are potentially pathogenic for birds were assessed.

\section{MATERIALS AND METHODS}

\section{Collection of samples:}

Measurements were conducted in a chicken broiler house, Qena province, Egypt. The house was visited weekly throughout the fattening period. The house characterized by floor that was fully available to the birds (floor-raised houses), naturally ventilated through windows along the sides and by fans along the barns. Litter consisted of wood shaving spread in the floor.

Over the 7-wk period of fattening, the environmental contamination by bacterial and fungal species were determined inside the house. Samples from air, litter and poultry feeds as well as water samples from drinker were randomly taken.

\section{Air samples:}

Air samples of $60 \mathrm{~L} / \mathrm{min}$ were collected by impaction method (Spin Air, IUL). The air sampler was placed $1.5 \mathrm{~m}$ from the ground level. 


\section{Litter and feed samples:}

One gram of each litter or feed sample was collected and introduced in McCartney tube containing $10 \mathrm{~mL}$ of buffered peptone water. After vigorous shaking, $1 \mathrm{ml}$ was used as inoculum.

\section{Water samples:}

Water samples were collected from the drinkers under aseptic conditions, then were evaluated for their microbiological quality.

\section{Microbiological Analyses:}

The agar plates were prepared and the following media were selected for recovery of total bacterial count Trypticase Soy Agar (TSA) supplemented with cyclohexamide ( $0.5 \%$ Sigma, USA), Staphylococci on Mannitol Salt Agar (MSA), coli-group bacteria on chromocult agar, fecal enterococci on Packers (enterococcus) agar and pseudomonads on cetrimide agar. Fungi were grown on Sabouraud-chloramphenicol dextrose agar plates. All media were from Biolab, Hungary except Chromocoult agar from Merck, Germany.

After sampling, colonies were counted after $48 \mathrm{~h}$ of incubation at 35 - $37^{\circ} \mathrm{C}$ for bacteria and after 6 days in $28^{\circ} \mathrm{C}$ for fungi. The incubation temperature of $40^{\circ} \mathrm{C}$ was selected to isolates only thermophilic fungal species that may behave as opportunistic pathogens for birds.

The bacterial and fungal contamination were estimated by counting the number of colony-forming units (CFU/ m3 for air samples, $g$ for litter and feed samples). The average number was calculated and transformed into $\log _{10}$ colony forming units. 
Water quality evaluation was determined by the most probable number (MPN) of coliforms, E. coli and fecal enterococci according to (АРHA, 1995).

\section{Isolates identification:}

The bacterial isolates were characterized and identified using the methods of Cowan and Steel(1990)and Holt et al.(1998) and microtests API systems (bioMerieux, Marcy I,Etoiles, France) were also used.

The fungi isolates were identified with the features described by Barnett and Hunter (1972; de Hoog et al., 2000).

\section{Data analysis:}

The average concentrations were calculated for each analyzing microbial group or species from duplicate plate counts. All counts were expressed as colony-forming units (CFU/ m3 for air samples, $g$ for litter and feed samples) and transformed into $\log _{10}$ colony forming units since the raw data was not normally distributed. The mean $\log _{10}$ values were determined.

\section{RESULTS}

A total of 96 environmental samples were collected as 21 samples from air, 24 from feed, 33 from litter and 18 from water. Bacterial colonies were detected in 14 air samples, 21 litter samples, and 11 feed samples. Fungal colonies were detected in 18 air samples, 21 feed samples, and 29 litter samples.

In general the analyzed air pollutants reached relatively high levels in the mid-fattening period and the airborne microbial contaminants levels at the end of fattening period were almost as those measured at the 
beginning (Figure 1). The results of microbiological analyses of air inside broiler house during the 7 week studying period are shown in Table 1. It has been stated that airborne bacteria were recorded at a mean value $\left(\log _{10} \mathrm{cfu} / \mathrm{m}^{3}\right)$ of 4.17 for aerobic bacteria; 1.86 for total coliforms; 0.89 for E. coli, 1.59 for fecal enterococci; 2.78 for Staphylococci; and 2.16 for Pseudomonads.

The concentration of airborne fungi was recorded at a mean value of $2.59 \log _{10} \mathrm{cfu} / \mathrm{m}^{3}$.

The microbiological evaluation of feed and litter samples (Table 2 and 3), the results detected a relatively high microbial contamination during the surveillance period.

The result of MPN for water samples from drinkers revealed massive contamination with coliform and fecal enterococci (Table 4).

The bacteriological examination indicated that Staphylococcus spp., fecal enterococci, and pseudomonads were the predominant bacterial contaminants recovered from environmental samples; whereas coliforms were in low level and E. coli was the most recovered among coliform bacteria (Table 5).

The results of mycological examination of the air, litter and feed samples is recorded in table 6, Aspergillus, Penicillium, Cladosporium and yeasts were the most prevalent genera. The most frequently encountered species were Aspergillus flavus, A. fumigatus, and Candida albicans. Other fungi were also encountered including Scopulariopsis spp., Alternaria spp. and fusarium spp. 


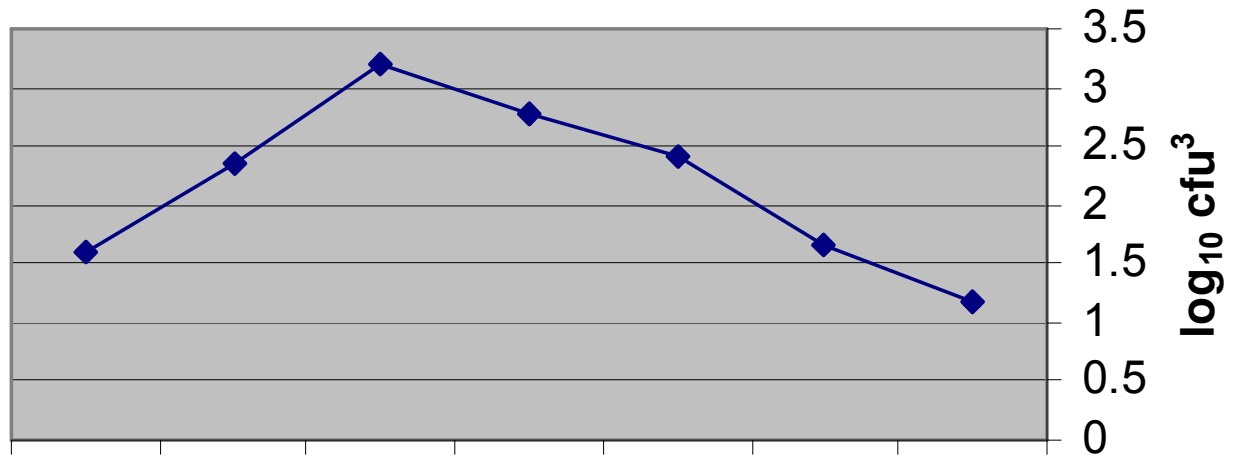

\section{Wk 7 Wk 6 Wk 5 Wk 4 Wk 3 Wk 2 Wk 1 Weeks}

Fig. (1): Microbial contamination of air samples

Table (1): Means of the enumerated microbial groups or specis $\left(\log _{10} \mathrm{cfu} / \mathrm{m}^{3}\right)$ recovered from air samples in a broiler house.

\begin{tabular}{||l||c||c||c||}
\hline \hline Microbial group or species & Initial concentration & Maximum concentration & Mean \\
\hline \hline Aerobic bacteria & 2.49 & 5.85 & 4.17 \\
\hline Total coliform & 0.77 & 2.96 & 1.86 \\
\hline Esherichia coli & 0.00 & 0.89 & 0.89 \\
\hline Fecal enterococci & 0.79 & 2.39 & 1.59 \\
\hline Staphylococci & 1.85 & 3.72 & 2.78 \\
\hline Pseudomonads & 1.12 & 3.21 & 2.16 \\
\hline Yeast and molds & 1.46 & 3.72 & 2.59 \\
\hline
\end{tabular}

Table (2): Means of the enumerated microbial groups or species $(\log 10$ $\mathrm{CFU} / \mathrm{g}$ ) recovered from chicken litter.

\begin{tabular}{||l||c||c||c||}
\hline \hline Microbial group or species & Initial concentration & Maximum concentration & Mean \\
\hline \hline Aerobic bacteria & 3.83 & 7.82 & 5.82 \\
\hline Total coliform & 1.39 & 4.73 & 3.06 \\
\hline Escherichia coli & 0.00 & 2.85 & 2.85 \\
\hline Fecal enterococci & 0.00 & 4.30 & 4.30 \\
\hline Staphylococci & 2.26 & 5.7 & 3.98 \\
\hline Pseudomonads & 3.10 & 5.14 & 4.12 \\
\hline Yeast and molds & 2.02 & 5.58 & 3.8 \\
\hline
\end{tabular}


Table (3): Means of the enumerated microbial groupsspecies $(\log 10 \mathrm{CFU} / \mathrm{g})$ recovered from chicken feed.

\begin{tabular}{||c||c||c||c|}
\hline \hline $\begin{array}{c}\text { Microbial group or } \\
\text { species }\end{array}$ & $\begin{array}{c}\text { Initial } \\
\text { concentration }\end{array}$ & $\begin{array}{c}\text { Maximum } \\
\text { concentration }\end{array}$ & Mean \\
\hline \hline Aerobic bacteria & 2.8 & 4.3 & 3.55 \\
\hline Total coliform & 1.9 & 3.8 & 2.85 \\
\hline Esherichia coli & 0.17 & 2.56 & 1.53 \\
\hline Fecal enterococci & 0.00 & 1.98 & 1.98 \\
\hline Staphylococci & 1.28 & 2.5 & 1.89 \\
\hline Pseudomonads & 1.10 & 2.41 & 1.75 \\
\hline Yeast and molds & 2.02 & 2.40 & 2.21 \\
\hline
\end{tabular}

Table (4): The most probable number values (MPN) of total coliforms, E. coli and fecal enterococci / $100 \mathrm{ml}$ water from drinkers in broiler house.

\begin{tabular}{|c||c||c|}
\hline Coliforms & $\boldsymbol{E}$. coli & Fecal enterococci \\
\hline \hline 440 & 90 & 70 \\
\hline 900 & 400 & 93 \\
\hline 1500 & 390 & 75 \\
\hline 1900 & 400 & 150 \\
\hline 2400 & 930 & 210 \\
\hline
\end{tabular}

Table (5): Pathogenic or potentially pathogenic bacterial species recovered from contaminated environmental samples in broiler house.

\begin{tabular}{||l||c||c|}
\hline \multicolumn{1}{|c|}{ Bacterial species } & No. of isolates & \% of 96 \\
\hline \hline E. coli & 11 & 11.4 \\
\hline Enterobacter cloacae & 3 & 3.1 \\
\hline Citrobacter freundii & 2 & 2.1 \\
\hline Enterococcus fecalis & 14 & 14.6 \\
\hline Klebsiella pneumonae & 2 & 2.1 \\
\hline Staphylococus aureus & 9 & 9.4 \\
\hline Staphylococcus intermedius & 2 & 2.1 \\
\hline Staphylococcus epidermidis & 13 & 13.5 \\
\hline Pseudomonas aeruginosa & 11 & 11.4 \\
\hline Pseudomonas fluorescence & 2 & 2.1 \\
\hline \hline
\end{tabular}

Table (7): Results of mycological examination of environmental samples taken from broiler house.

\begin{tabular}{||l||c||c|}
\hline \multicolumn{1}{|c||}{ Species } & No. of isolates & \% of 96 \\
\hline \hline Absidia corymbifera & 1 & 1.0 \\
\hline Alternaria alternata & 2 & 2.1 \\
\hline Aspergillus flavus & 26 & 27.1 \\
\hline Aspergilus fumigatus & 3 & 3.1 \\
\hline Aspergillus niger & 19 & 19.8 \\
\hline Aspergillus egyptiacus & 1 & 1.0 \\
\hline Cladosporium herbarum & 9 & 9.4 \\
\hline Fusarium moniliforme & 4 & 4.2 \\
\hline Penicillium chrysogenum & 11 & 11.4 \\
\hline Scopulariopsis brevicaulis & 7 & 14.6 \\
\hline Candida albicans & 13 & 9.4 \\
\hline
\end{tabular}




\section{DISCUSSION}

The intensive poultry breeding requires high nutritional requirements and proper environmental conditions. Air quality and safe environments are an important consideration for animal houses and surrounding livings. Consequences of poor air quality include decreased production performance and poor bird health.

Numerous investigators have assessed the microbiological status of air pollution on poultry farms and its impacts on poultry health and productivity and stated that air concentration of microorganisms in poultry housing was greatly varies, which could in part be ascribed to different methods of sampling used in previous studies. The concentration of airborne microorganisms in layer housing to range from 360 to 3781 cfu/l air Hartung (1994) and Müller (1987) from 17 to $5860 \mathrm{cfu} / \mathrm{l}$ air. In the extensive study carried out by Seedorf et al. (1998), total airborne microorganism concentration in animal housing, expressed as a logarithm, was about $9.5 \mathrm{log} \mathrm{cfu} / \mathrm{h}$ per $500 \mathrm{~kg}$ body weight (b.w.) in broiler houses. Northcutt et al. (2004) reported total aerobic bacteria $\log _{10}$ counts of 6.4 and 5.5 to 5.9 for broiler and hen houses, respectively. Meanwhile in Egypt, Sotohy (1989); Draz and Samaha (1992); Byomi and Trabees (2006) also detected airborne microorganisms in broiler and hen houses air in cfu/l. The Coliforms particularly, E. coli, and fecal enterococci that are part of intestinal flora of man and animals and consider as a bioindicator of pollution. Hojovec et al. (1977) evaluated the air quality in poultry house using E. coli as an indicator. Our results revealed coliforms and E. coli were detected at a mean values of 1.86 and $0.89 \log _{10}$ in air of the examined house, respectively. Past investigation revealed that the ambient air of animal 
houses is often polluted with airborne E. coli (Zucker et al., 2000; Duan et al. 2006). The obtained results were relatively similar to those reported by Draz and Samaha(1992)and El Zarka (2003). Northcutt et al. (2004) found that coliform counts were highest in air sampled in the hen house (2.5 $\left.\log _{10} \mathrm{cfu} / \mathrm{ml}\right)$. The coliforms and E. coli concentrations in air of poultry houses are correlated to their concentration in litter, feeds, biological activity of birds and stocking density (Hojovec and Fisher, 1986; Lovett et al., 1971). Moreover, the other fecal indicator, fecal enterococci, was reported at a mean value of $1.59 \log _{10}$ in air. This was relatively similar with the previously reported fecal enterococci in the air of hen houses by El-Zarka (2003); Byomi and Trabees (2006). The plate counts of Enterococcus spp. appeared to reflect their relative abundance among chickens normal flora of gastrointestinal tract (Zhu et al., 2002). Counts for Staphylococci and Pseudomonads were highest in the house (2.78 and $2.16 \log _{10}$, respectively). Our results were in coincided with the past investigations that detected relatively higher prevalence of Staphylococci and Pseudomonads in poultry houses (Northcutt et al., 2004; Byomi and Trabees, 2006).

The mycological investigation of air in the house revealed total fungal count at a mean of $2.59 \log _{10}$ and Aspergillus in addition to yeasts of genus Candida were the predominant genera encountered. Northcutt et al. (2004) and Fulleringer et al. (2006) detected mold and yeast count in a higher concentration in air of poultry house. In Egypt, Past investigations revealed higher prevalence of fungi in the ambient air of poultry houses as Aspergillus spp., Penicillium spp., Cladosporium spp., Scopulariopsis spp., Absidia spp., in addition to yeasts of genus Candida were the predominant genera encountered (Swelim et al., 1993; Moawed et al., 1995). 
The results revealed that the air concentration of microorganisms increased with the bird growth and age whereas low at the beginning and end of fattening period, which was attributed to limited birds activity. Similar conclusions were also reported by Saleh et al. (2005) and Vucemilo et al. (2007) investigating the effect of fattening poultry age and season on the bioaerosol concentration in poultry houses. Furthermore, Sauter et al. (1981) reported that the airborne microflora increased with the density housing of birds.

Other factors influence the air concentration of microorganisms. The microbiological evaluation of litter, feed and water from the house were detected to be contaminated with the microbial groups or species analyzed. In poultry industry, the use of feed and water with adequate microbiological quality, it is of fundamental importance. Since many birds have access to the same water and feed sources, quality problems will affect a great number of animals. Fulleringer et al. (2006) reported constant fungal contamination of litter and poultry feed through out the surveillance periods. Byomi and Trabees (2006) revealed massive contamination of water sources with fecal enterococci and coliforms. Arotupin et al. (2007) recorded highest bacterial and fungal counts in commercial poultry feeds. Litter is a major factor because the population of microorganisms varies depending on the dynamics of litter exchange (Lu et al., 2003; Vucemilo et al., 2007).

The bacterial and fungi genera detected in the present study were consistent with literature data (Sweilem et al., 1993; Hartung, 1994; Moawed et al., 1995; Seedorf et al., 1998; Baykov and Stoyanov, 1999; Szejniuk and Kuczek, 2000; Radon et al., 2002; Bakutis et al., 2004; 
Byomi and Trabees, 2006; Fulleringer et al., 2006). The different bacterial and fungal species that were isolated during the study period are considered pathogenic and or potentially pathogenic for chickens. $S$. aureus is a common cause of synovitis and arthritis which is a septicemic staphylococcal infection localized in the joints and tendon sheaths leading to bumble foot (Devries et al., 1975). Coli-group bacteria and $E$. coli are known to be a diarrheic agents. Furthermore, Aspergillus flavus, Aspergillus fumigatus and Candida albicans are causes of avian aspergillosis and candidosis.

In conclusions, This study was contributing to the understanding of the level and composition of environmental pollutants in poultry house. It could be concluded that analysis of the microbial contamination of a poultry house is necessary for taking suitable hygienic measure to improve bird health performance, human health and surrounding environment as well.

\section{REFERENCES}

- Al Maghlouth, A., Al Yousef, Y., \& Al Bagieh, N. (2004). Qualitative and quantitative analysis of bacterial aerosols. J. Contemp. Dent. Pract., 5, 91- 100 .

- American Public health Association (APHA) (1995). Standard methods for the examination of water and waste water, 19th ed. American Public health Associaiton, Washington, D.C.

- Arotupin, D. J., Kayode, R. M. O., and AwoJobi, K. O. (2007). Microbiological and physicochemical qualities of selected commercial poultry feeds in Akure, Nigeria. J. Biol. Sci., 7, 981-984. 
- Bakutis, B., Monstviliene, E., and Januskeviciene, G.(2004). Analyses of airborne contamination with bacteria, endotoxins and dust in livestock barns and poultry houses. Acta Vet. Brno, 73, 283-289.

- Barnet,H.L., and Hunter, B. B.(1972). Illustrated genera of imperfect fungi. $3^{\text {rd }}$ Edn., Burges publishing company Minneopolis, pp:33.

- Baykov, B., and Stoyanov, M. (1999). Microbial air pollution caused by intensive broiler chicken breeding. Microbiol. Ecol., 29, 389-393.

- Byomi, A. M., and Trabees, R. Z. (2006). Hygienic status of some egg laying farms under different housing systems. Minufiya Vet. J., 4, 119-133.

- Clark, S., Rylander, R., and Larsson, L. (1983). Airborne bacteria, endotoxin and fungi in dust in poultry and swine confinement buildings. Am. Ind. Hyg. Assoc. J. 44, 537-541.

- Cowan, S. T., and Steel, K. J. (1990). Manual for the identification of medical bacteria. $4^{\text {th }}$ Edn., Cambridge University press, pp: 22-29.

- De Hoog, G. S., Guarro, J., Gene, J., and Figueras, M. J. (2000). Atlas of clinical fungi. $2^{\text {nd }}$ Edn., Centraalburue voor schimmelcultures, Utrecht, The Netharlands.

- Deveries, L. A., Devos, A. H., and Domme, L. A. (1975). Quantitative aspects of the Staphylococcus aureus flora of poultry. Poult. Sci., 54, 95-101.

- Donham, K. J. (1993). Respiratory disease hazards to workers in livestock and poultry confinement structures. Semin. Respir. Med. 14, $49-59$. 
- Draz, A. A., and Samaha, H. A. (1992). Microbial air pollution inside some poultry houses in Minufyia Governorate. Assiut Vet. Med. J., 26, 114-120.

- Duan H. Y., Chai T. J., and Wang Y. X. (2006). Concentration of airborne endotoxins and airborne bacteria in Chinese rabbit houses. Berl. Münch. Tierärztl. Wochenschr., 119, 40-44.

- Duan, H.Y., Chai, T. J., Cai, Y. M., Zhong, Z.B., Yao, M. L., and Zhang, X. X. (2008). Transmission identification of Escherichia coli aerosol in chicken houses to their environments using ERIC-PCR. Sci. China Ser. C-Life Sci., 51,164-173.

- El-Zarka, R. (2003). The role of environment inside poultry houses in disease occurrence. Ph.D. Thesis, Fac. Vet. Med., Alexandria University, Egypt.

- Fulleringer, S. L., Seguin, D., Warin, S., Bezille, A., Desterque, C., Arne, P., Chermette, R., Bretagne, S., and Guillot, J. (2006). Evolution of the environmental contamination by thermophilic fungi in a turkey confinement house in France. Poult. Sci., 85, 1875-1880.

- Hartung, J. (1994). The effect of airborne particulates on livestock health and production. In: I. AP DEWI (ed.): Pollution in Livestock Production Systems. CAB International, Wallingford, UK, 55-69.

- Hojovec, J., and Fiser, A. (1986). Microflora in the atmosphere of chicken houses for broilers. Dt. Tierartzl. Wochenschr., 75, 483.

- Hojovec, J., Fiser, A., and Kubicek, K. Z. (1977). Die Rolle von Indikator keimen fuer die Beurteilung der Stalluft. Mh.Vet. Med., 32, 766-769. 
- Holt, J. G., Keng, N. R., Atwill, E. R., and Cullor, J. S. (1998).

Prevalence of selected microbial pathogens in processed poultry waste used as dairy cattle feed. Poult. Sci., 77, 808-811.

- Karwowska, K. (2005). Microbiological air contamination in farming environment. Polish J. Environ. Studies 14, 445-449.

- Lovett, J., Messer, J. W., and Reed, R. B. (1971). The microflora in southern Ohaio poultry litter. Poult. Sci., 50, 746-751.

- Lu, J., Sanchez, S., Hofacre, C., Maurer, J. J., Harmon, B. G., and Lee, M. D. (2003). Evaluation of Broiler Litter with Reference to the Microbial Composition as Assessed by Using 16S rRNA and Functional Gene Markers. Applied and Environ. Microbiol., 69, 901908.

- Moawed,S. M.,Abdel-Hafez,S. I.I., Moharram, A. M., \& Gherbawy, Y. A. M. (1995). Mycoflora of hair, feather and flooring materials under cows and chicken at Qena, Egypt. Cryptogamie Mycol., 16, 223-236.

- Müller W. (1987). Origin, quantity and quality of microbial emissions in animal houses. In: Strauch, D. Edn. Animal Production and Environmental Health. Amsterdam, Elsevier Science Publishers, B6, 66-71.

- Northcutt, J. K., Jones, D. R., Ingram, K. D., Hinton, A., Musgrove, M. T., and Musgrove, Jr. (2004). Airborne microorganisms in commercial shell egg processing facilities. Inter .J. Poult. Sci., 3, 195200. 
- Radon, K., Danuser, B., Iversen, M., Monso, E., Weber, C., Hartung, J., Donham, K., Palmgren, U., and Nowak, D. (2002). Air contaminants in different European farming environments. Ann. Agric. Environ. Med., 9, 41-48.

- Ritz, C. W., Mitchell, B. W., Fairchild, B. D., Czarick III, M., and Worley, J. W. (2006). Improving in-house air quality in broiler production facilities using an electrostatic space charge system. J. Appl. Poult. Res., 15, 333-340.

- Saleh, M., Seedorf, J., and Hartung, J. (2005). Influence of animal age and season on bioaerosol concentrations in broiler house. In: Proc. 12th Int. Congress on Animal Hygiene. September 4-8, Warsaw, Poland, 2, 37-40.

- Sauter, E. A., Petersen, C. F., Steele, E. E., Parkinson, J. F., Dixon, J. E., and Stroh, R. C. (1981). The airborne microflora of poultry houses. Poult. Sci., 60, 569-574.

- Seedorf, J., Hartung, J., Schroeder, M., Linkert, K. H., Phillips, V. R., Holden, M. R., Sneath, R. W., Short, J. L., White, R. P., Pedersen, S., Takai, H., Johnsen, J. O., Mertz, J. H. M., Groot Koertkamp, P. W. G., Uenk, G. H., and Wathes, C. M. (1998). Concentrations and emissions of airborne endotoxins and microorganisms in livestock buildings in Northern Europe. J. Agri. Eng. Res., 70, 97-109.

- Sotohy, A. S. (1989). Hygienic significance of some microbial isolates from broiler houses. M. V. Sc. Thesis, Fac. Vet. Med. Assiut University, Egypt. 
- Swelim, M. A., El-Dohlob, S. M., Hazzaa, M. M., \& El-Sayed, T. I. (1993). Studies on mycoflora of poultry farms at Qalubia district, Egypt. 1.- air-spora in poultry farms. Bulletin of the Faculty of Science, Assiut Univ. (Egypt), 22, 11-24.

- Szejniuk B., and Kluczak J. P. (2000). The bacteria from Enterobacteriaceae family and other gram-negative microorganisms in poultry houses. In: Proc. $10^{\text {th }}$ Int. Congress on Animal Hygiene. July 2-6, Maastricht, Netherlands, 2, 609-612.

- Vucemilo, M., Matkovic, K., Vinkovic, B., Jaksic, S., Granic, K., and Mas, N. C. (2007). The effect of animal age on air pollutant concentration in a broiler house. Czech J. Anim. Sci., 52, 170-174.

- Whyte, R. T. (1993). Aerial pollutants and health of poultry farmers. World. Poult. Sci. J. 49, 139-156.

- Whyte, P., Collins, J. D., McGill, K., Monahan, C., and O'Mahony, H. (2001). Distribution and prevalence of airborne microorganisms in three commercial poultry processing plants. J. Food Prot., 64, 388391.

- Zhu, X. Y., Zhong, T., Pandya, Y., and Joerger, R. D. (2002). 16S rRNA-based analysis of microbiota from the cecum of broiler chickens. Appl. Environ. Microbiol., 68,124-137.

- Zucker, B.A., Trojan, S., and Muller, W. (2000). Airborne gramnegative bacterial flora in animal houses. J. Vet. Med. B, 47, 37-46. 


\section{تحليل التلوث البيئي بالبكتيريا والفطريات في احدي بيوت (حظائر)}

\section{بلداري التسمين بمحافظة قنا - مصر}

\section{صبري عبل الرجال حسن محد 1" و بيوسف احد محد غرباوي 2 \\ 1 قسم الميكروبيولوجيا - كلية الطب البيطري - جامعة جنوب الوادي - قنا - مصر \\ 2 قسم النبات ( شعبة الميكروبيولوجي) - كلية العلوم - جامعة جنوب الوادي - قنا - مصر}

ترتبط صحة الطيور بدرجة كبيرة بجودة البيئة المحيطة بالطائر. تم دراسة الحالة الميكروبيولوجية في بيئة احدي حظائر بداري التسمين بمحافظة قنا - مصر . كانت المعايير المختبرة

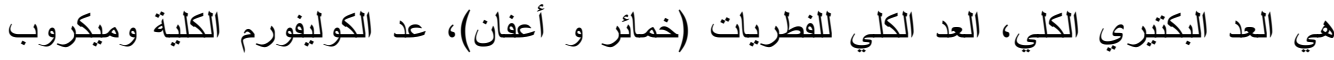
إيشيرشيا القولون، الميكروب السبحي البرازي، المكورات العنقودية و البكتيريا من جنس الزائفات

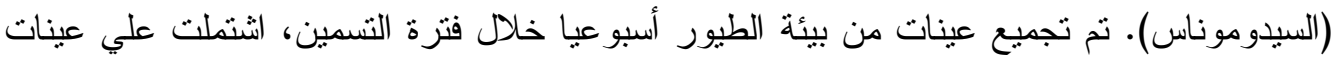
من علائق التسمين، فرشة الطيور ، مياه السقايات و الهو اء. تم عزل وتعريف البكتيريا و الفطريات من العينات البيئية المختلفة باستخدام الأوساط الغذائية التفريقية و الانتقائية المناسبة وكذلك

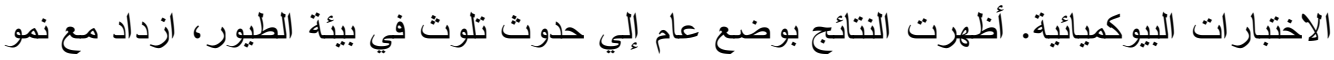

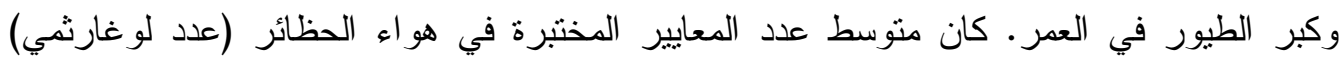
كالتالي: العد البكتيري الكلي 4.17 ، العد الفطري الكلي 2.59 ، عدد الكوليفورم الكلية 1.86 ،

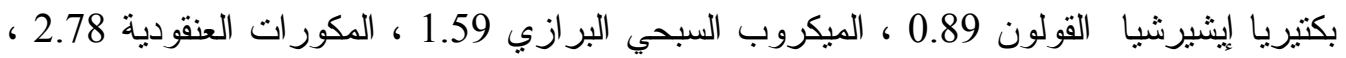

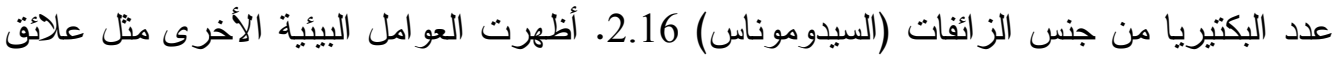

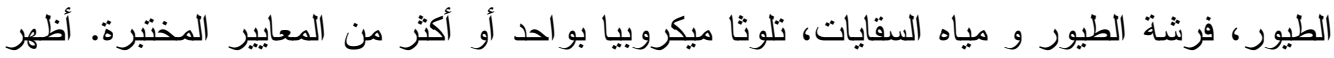
الفحص البكتريولوجي للعينات البيئية المختلفة إلي شيوع عزل البكتيريا من جنس المكورات

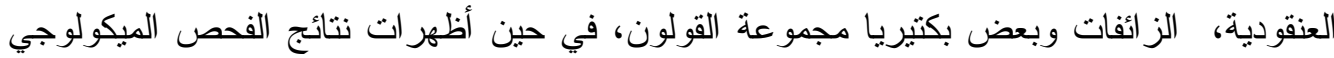

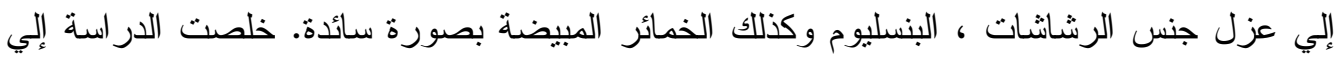

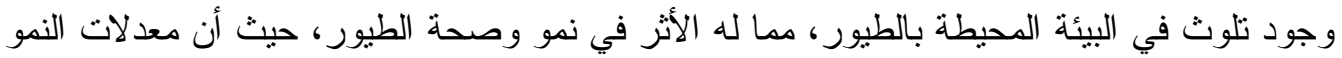

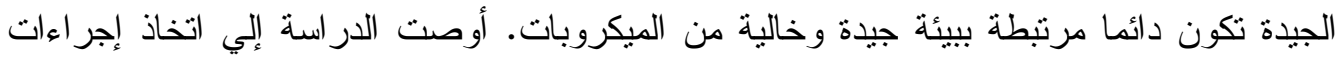
صحية مثل النطهير وغيرة، من شأنها ضبط البيئة المحيطة بالطيور لوقاية الطيور من الإصابة ببعض الميكروبات وكذلك العاملين القائمين علي رعاية الطيور وتربيتها ومنع حدوث ثلوث للبيئة

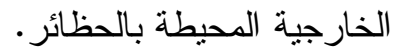

